\title{
EFFECT OF GLYPHOSATE, SALICYLIC ACID, NITROGEN AND ORGANIC FERTILIZATION ON BROOMRAPE CONTROL AND FABA BEAN PRODUCTIVITY
}

\author{
S.H.M. Abd-El-Haleem ${ }^{(1)}$, A.A.O. Fakkar (2), Y. A.M. Khalifa ${ }^{(1)}$ \\ and A.H.A. Ibrahim ${ }^{(1)}$ \\ (1) Department of Agronomy, Faculty of Agriculture, Al-Azhar University, Assiut, Egypt. \\ (2) Weed Research Central Laboratory, Agriculture Research Center, Giza, Egypt.
}

Received: Mar. 10, 2019

Accepted: Sep. 22, 2019

\begin{abstract}
In Upper Egypt, the level of broomrape infestation is so high because of high temperature which led to decline of faba bean area. The control of two field experiments were conducted in a heavy infested soil with broomrape in Shandaweel Research Station, Sohag Governorate, Agricultural Research Center during 2016/17 and 2017/18 winter seasons to study the effected potential integration between nitrogen and manure fertilizers hand pulling and interaction between selective herbicides and salicylic acid on control for broomrape and increased faba bean productivity. Each experiment contained three levels of (nitrogen fertilization at rate $20 \mathrm{~kg} / \mathrm{fed}$., organic manure fertilizers at rate $20 \mathrm{~m}^{3} / \mathrm{fed}$, nitrogen fertilization at rate $10 \mathrm{~kg} / \mathrm{fed}+$ organic manure fertilizers at rate $10 \mathrm{~m}^{3} / \mathrm{fed}$ and without fertilizer (untreated check) and eight broomrape control treatments (Glyphosate twice at rate $75 \mathrm{~cm}^{3} / \mathrm{fed}$ - Glyphosate once at rate 75 $\mathrm{cm}^{3} / \mathrm{fed}$. + Salicylic acid once at $200 \mathrm{mg} / \mathrm{one}$ liter water - Glyphosate once at rate 50 $\mathrm{cm}^{3} / \mathrm{fed}+$ Salicylic acid once at $\mathbf{2 0 0} \mathrm{mg} / \mathrm{one}$ liter water - Salicylic acid thrice at rate 200 mg/one liter water - Hand pulling twice and untreated (control). Split plot design in three replications were used. Faba bean cultivar was Giza -843 and plot area was $10.5 \mathrm{~m}^{2}$.
\end{abstract}

The results revealed that fertilizers reduced significantly Orobanche infestation in 2016/17 and 2017/18 seasons. Addition of $20 \mathrm{~kg} \mathrm{~N}$-fertilizer/fed and N-fertilization at $10 \mathrm{~kg}$ $/$ fed + O.M-fertilizers at $10 \mathrm{~m}^{3} /$ fed increased number plants of faba bean/plot by (10.28 \& $6.84 \%)$ and (2.84 \& 1.18\%), decreased number of plant infestation/plot by (33.41 \& $17.40 \%)$ and (13.86 \& 10.58\%), number of broomrape spikes/plot by (31.49 \& 22.16\%) and (15.44 \& 12.83\%) and dry weight broomrape spikes/plot by (31.38 \& 22.00\%) and (15.45 \& 12.84\%) in 2016/17 and 2017/18 seasons, respectively, compared with non-fertilizer check. Nitrogen fertilization and nitrogen fertilization +Organic manure fertilizer recorded the highest values for plant height $(\mathrm{cm})$, number of branches/plant, number of pods/plant, weight of pods/plant (g), seed weight/plant (g), 100-seed weight (g) and seed yield /fed in both seasons compared with non-fertilizer.

Broomrape control treatments decreased significantly numbers and weight broomrape spikes (g/plot) of Orobanche in 2016/17 and 2017/18 seasons. Glyphosate at rate twice at $75 \mathrm{~cm}^{3} /$ fed and Glyphosate once at rate $75 \mathrm{~cm}^{3} / f e d$. Salicylic acid once at $200 \mathrm{mg} / \mathrm{one}$ liter water increased number plants of faba bean/plot by (12.44 \& 12.35\%) and (4.61 \& $4.12 \%)$ and decreased the number of plant infestation of faba bean/plot by $(59.43 \&$ $46.69 \%)$ and (52.52 \& 51.54\%), number of broomrape spikes /plot by (55.06 \& 50.64\%) and (49.63 \& 49.48\%) and dry weight of broomrape spikes/plot by (55.10 \& 50.69\%) and (49.62 \& $49.47 \%$ ) in 2016/17 and 2017/18 seasons, respectively, as compared with untreated (control). Glyphosate at rate twice and glyphosate once + Salicylic acid once gave the heist values number of pods/plant, weight of pods/plant $(g)$, seed weight/plant $(g), 100$ - 
S.H.M. Abd-El-Haleem, et al.,

seed weight and seed yield /fed. in both seasons compared with untreated check in both seasons.

Through this study, salicylic acid can be used as a safe alternative to plants and the environment as a new trend in broomrape control and increasing the production of faba bean.

Key words: Glyphosate, Salicylic acid, broomrape control, faba been.

\section{INTRODUCTION}

In the Nile valley, Egypt, faba bean fields are often infested with Orobanche spp. In Middle and Upper Egypt, the level of infestation is so high that there has been a complete crop failure the yield losses usually due to Orobanche infestation is proportional according to the level of infestation which could reach up to $90-100 \%$ (Anonymous, 1994) and (Saxena et al. 1994) by $5-100 \%$. The control of this parasitic weed is very difficult because no measure adequate by itself for controlling Orobanche. Further, due to many reasons as the late attachment to the host make the use of pre-emergence herbicides not suitable in one side, also limited selectivity with post-emergence herbicides in faba bean.

Many researchers reported that the high nitrogen application reduced development of Egyptian broomrape and crenata broomrape as reported by Van Hezewijk et al. (1991). Demonstrated significant reductions of Orobanche crenata Forsk in faba bean following applications of ammonium sulfate equivalent to 14 and $28 \mathrm{~kg} \mathrm{~N} / \mathrm{ha}$. Pieterse (1991) reported that nitrogenous fertilizers reduced crenate broomrape seed germination and radical length of germinated seedlings.

Urea and ammonium sulfate were shown to decrease the percentage of seed germination and radical elongation of crenate broomrape when applied during pre-conditioning and germination (Pieterse 1991). Jain and Foy (1992) stated that the effects of $\mathbf{N}$ from different sources had different inhibitory effects. Experiments on the direct effects of nitrogen on broomrape seeds strongly implicate the reduced forms of nitrogen such as urea, ammonium sulfate. Demirkan and Nemli (1994) demonstrated that high soil nitrogen fertility has been suggested to reduce the severity of crop damage caused by broomrape. Nandula et al. (1996) found that the effects of $\mathrm{N}$ from different sources had different inhibitory effect on broomrape seeds. Ismail (2013) revealed that adding 10 and $20 \mathrm{~kg} \mathrm{~N} / \mathrm{fed}$ reduced Orobanche infestation by 22.3 and $43.9 \%$, while improved seed yield by 14.9 and $13.1 \%$, respectively, than unfertilized plots. Organic manure improved seed yield by 1.5 and $4.2 \%$, respectively, than without manure. Fakkar et al (2016) indicated that the mineral fertilizer reduced both the number and weight of broomrape spikes followed by organic fertilizer recorded the highest values of yield and yield attributes as compared with the unfertilized.

Herbicides and Salicylic acid are the most important of the available methods for Orobanche spp. control. Ward et al (1991) indicated that Salicylic acid (SA) is a chemical defence-inducer that enhanced resistance to various pathogens and induces disease resistance and systemic acquired resistance (SAR) gene expression. Gorlach et al (1996) demonstrated that Benzothiadiazole (BTH) is a synthetic functional analogue of SA and its application to plants has been proposed to be an applicable strategy to control Orobanche parasitism. Al-Marsafy et al (2001) revealed that increased faba bean seed yield by 416,372 and $312 \%$ obtained by the application of glyphosate twice and/or Orobanche hand-pulling twice $\mathbf{3 0}$ and 110 days after sowing compared to the untreated check. Luque et al (2004) 
noted that the effect of salicylic acid reduced broomrape infection under controlled conditions by limiting the success in attachment and retarding the development of established tubercles. Gonsior et al (2004) revealed that (SA) applications reduced the total Orobanche. foetida number and the number of tubercles reaching stage 5 , but did not induce necrosis of developing parasite tubercles. Kusumoto et al (2007) stated that in clover, root application of (SA) and (BTH) significantly reduced the number of established Orobanche. minor parasites by more than $75 \%$. Ismail and Fakkar (2008) noted that the best treatments for faba bean yield and quality were achieved from hand pulling twice. Also, they found is applied (SA) increased plant's tolerance to several a biotic stresses and also influence a range of diverse processes in plants, including seed germination, stomata closure, ion uptake and transport, membrane permeability, photosynthesis and plant growth rate (Aftab et al. (2010). Bayoumi et al (2013) indicated that application of glyphosate at $75 \mathrm{~cm}^{3} / \mathrm{fed}$ recorded the lowest broomrape population by $85.85 \%$. Ismail (2013) stated that application of glyphosate alone or as complement with hand pulling gave higher reduction in the number and weight of broomrape by 97.1 , $97.1,97.0$, and $97.3 \%$, respectively, as compared with untreated chick and improved seed yield by 75.6 and $72.1 \%$, respectively. El-Metwally et al (2013) reported that glyphosate application three times significantly increased seed yield over the unweeded check by $85.1 \%$. Abbes et al (2014) found that (SA) and (BTH) applications reduced the total number of faba bean broomrape spike by $46.45 \%$ and $77.06 \%$, and the dry weight of broomrape spike by $47.03 \%$ and $70.3 \%$, respectively. El-Rokiek et al (2015) found that the maximum yield was obtained by the addition of ammonium sulfate to glyphosate at $37.5 \mathrm{ml} / \mathrm{fed}$ compared with the infected control. Fakkar et al (2016) stated that foliar application of glyphosate two times significantly decreased the number, dry weight of broomrape. Hand pulling twice and application of glyphosate two times $50+75$ caused increase in faba bean seed yield of 75.8 and $72.2 \%$, respectively. Eid et al (2017) indicated that foliar application glyphosate twice significantly decreased the number and dry weight of broomrape spikes $/ \mathrm{m}^{2}$ by 75.2 and $73.1 \%$ in the first season and by 72.6 and $69.8 \%$ in the second season, respectively, while the increased seed yield /fed. were 89.1 and $86.3 \%$ in the first and second seasons, respectively, as compared with untreated check.

So, this study is aimed to estimate the magnitude of contribution of the use of mineral and manure fertilizers, hand pulling and selective herbicide alone or as in integration with each other for controlling broomrape and study their effect on yield and its components of faba bean.

\section{MATERIALS AND METHODS}

Two field experiments were conducted at Shandaweel Research Station, Sohag Governorate during 2016/17 and 2017/18 winter seasons to study the effect of nitrogen, organic manure fertilizers and broomrape control in faba bean crop in naturally infested soil with broomrape. Soil texture of the experimental plots in both seasons was sandy loam.

\section{Soil analysis}

Surface soil samples $(0-30 \mathrm{~cm})$ were collected before planting from the experimental sites in two seasons for physical and chemical characters and their data is listed in Table (1). 
S.H.M. Abd-El-Haleem, et al.,

Table (1): Soil characterization for the experimental site.

\begin{tabular}{|l|l|c|c|c|c|c|c|c||}
\hline \multirow{2}{*}{ Seasons } & \multirow{2}{*}{ Texture } & \multirow{2}{*}{$\mathrm{CaCO}_{3} \%$} & \multirow{2}{*}{$\begin{array}{c}\text { Soil } \\
\mathrm{pH}\end{array}$} & $\begin{array}{c}\text { O.M } \\
\%\end{array}$ & \multicolumn{4}{|c|}{ Available nutrients in soil (ppm) } \\
\cline { 5 - 9 } & & & & $\mathrm{N}$ & $\mathrm{P}$ & $\mathrm{K}$ & $\mathrm{Zn}$ \\
\hline $2016 / 17$ & Clay loom & 7.70 & 7.8 & 1.2 & 18.5 & 18 & 38 & 0.47 \\
\hline $2017 / 18$ & Clay loom & 7.82 & 7.8 & 1.05 & 20 & 22 & 40 & 0.52 \\
\hline
\end{tabular}

Each experiment included twenty four treatments which were in combination of four fertilization treatments and six broomrape control treatments in a split plot design in three replications as follows:

\section{A- Main plots: Fertilization}

1- Nitrogen fertilization was soil applied as ammonium sulphate $(33.5 \% \mathrm{~N})$ at a rate of $20 \mathrm{~kg} \mathrm{~N} / \mathrm{fed}$ before the first and the second irrigations of faba bean.

2- Organic manure fertilizers (Table 2) at a rate of $20 \mathrm{~m}^{3} / \mathrm{fed}$ was applied before sowing.

3- Nitrogen fertilization at rate $10 \mathrm{~kg} / \mathrm{fed}$ + Organic manure fertilizers at rate 10 $\mathrm{m}^{3} / \mathrm{fed}$

4- None fertilization (untreated check).

\section{B- Sub plots: Broomrape control treatments:}

1-Foliar application of Glyphosate, 2 times with equal rate of $75 \mathrm{~cm}^{3} / \mathrm{fed}$, applied at the beginning of the flowering stage with 21 days interval between two applications.

2-Foliar application of Glyphosate, one time with equal rate of $75 \mathrm{~cm}^{3} / \mathrm{fed}$ at the beginning of the flowering stage followed by foliar application of Salicylic acid at $200 \mathrm{mg} /$ one liter water at 30 days after planting.

3- Foliar application of Glyphosate, one time at a rate of $50 \mathrm{~cm}^{3} / \mathrm{fed}$, at the beginning of the flowering stage + foliar application of Salicylic acid at 200 $\mathrm{mg} /$ one liter water at $\mathbf{3 0}$ days after planting.

4- Foliar application of Salicylic acid thrice at faba bean germination is complete, at $\mathbf{3 0}$ days after planting and beginning of the flowering stage at rate of $200 \mathrm{mg} / \mathrm{one}$ liter water solution of the corresponding times.

5-Hand pulling twice.

6-Untreated (control).

Salicylic acid (SA) $\left(\mathrm{C}_{7} \mathrm{H}_{6} \mathrm{O}_{3}\right)$ : Salicylic acid or 2-hydroxybenzoic acid was prepared by solving SA in ethyl alcohol. Every sub-sub plot which was treated with SA received $200 \mathrm{mg}$.

Glyphosate (48\% WSC): N(phosphonomethyl) glycine.

Faba bean cultivar (Giza- 843) was planted in $12^{\text {th }}$ and $18^{\text {th }}$ November in during 2016/2017 and 2017/2018 respectively, with a rate of $35 \mathrm{~kg}$ seeds/feddan. The sub sub plot area was $10.5 \mathrm{~m}^{2}$ contains five rows $3.5 \mathrm{~m}$ length and $60 \mathrm{~cm}$ apart. The normal cultural practices were carried out according to the local recommendations. The herbicidal treatments were sprayed with a knapsack sprayer with one nozzle boom. The water volume used was 200 liters/fed. 
Effect of glyphosate, salicylic acid, nitrogen and organic fertilization ...........

Table (2): Chemical analysis of farm yard manure (FYM) applied in the trait:

\begin{tabular}{|c|c|c|c|c|c|c|c|}
\hline Component & $\begin{array}{c}\text { Organic } \\
\text { matter \% }\end{array}$ & $\mathrm{pH}$ & $\begin{array}{c}\text { Total } \\
\text { nitrogen \% }\end{array}$ & $\begin{array}{c}\text { Organic } \\
\text { carbon \% }\end{array}$ & $\begin{array}{c}\mathrm{C} / \mathrm{N} \\
\text { Ratio }\end{array}$ & $\mathbf{P} \%$ & $\mathrm{~K} \%$ \\
\hline $\begin{array}{c}\text { Fertilizer } \\
\text { of (FYM) }\end{array}$ & 20.02 & 7.7 & 0.49 & 11.61 & 23.69 & 0.24 & 1.10 \\
\hline
\end{tabular}

Data recorded:

A-Broomrape:

The following data were recorded:

1-Number of plants of faba bean/plot $\left(10.5 \mathrm{~m}^{2}\right)$.

2-Number of infested faba bean plants/plot $\left(10.5 \mathrm{~m}^{2}\right)$.

3-Number of broomrape spikes/plot.

4-Weight of broomrape spikes/plot (g).

5-Broomrape incidence \% =

No. of infested host plants by broomrape

Total number of host plant(faba bean)

6-Broomrape severity = Average number of spikes/host plant.

\section{B - Yield and its components}

At harvest in mid-April, samples of ten faba bean plants were collected at randomly from the central rows of each plot to study the following criteria: plant height $(\mathrm{cm})$, number of branches/plant, number of pods/plant, weight of pods (g/plant), seed weight (g/plant) and 100seed weight $(g)$. Seed yield/fed. were estimated from the whole of each plot.

\section{Statistical analysis:}

The collected data were statistically analyzed according to the method described Snedecor and Cochran (1981). Least Significant Differences (LSDreceived) test was used for comparison between means of treatments.

\section{RESULTS AND DISCUSSION}

A- Effect of fertilization treatments

1- Broomrape characters

Data in Table (3) revealed that fertilizer increased significantly number of faba bean plants/plot $\left(10.5 \mathrm{~m}^{2}\right)$ but reduced no. of infested faba bean plants, no. of broomrape spikes and dry weight spikes/plot of broomrape compared with un fertilizerd 2016/17 and 2017/18 seasons.

Nitrogen fertilization at a rate of $20 \mathrm{~kg}$ $\mathrm{N} / \mathrm{fed}$ before the first and the second irrigations of faba bean and nitrogen fertilization at $10 \mathrm{~kg} / \mathrm{fed}+$ Farm yard manure at a rate of $10 \mathrm{~m}^{3} / \mathrm{fed}$ (Organic manure) increased significantly number of faba bean plants/plot by $(11.46 \%$ and $10.18 \%)$ in $2016 / 17$ season and by $(2.84$ and $1.18 \%$ ) in 2017/18 season, respectively, compared to without fertilizer treatment.

Nitrogen fertilization and nitrogen fertilization +Organic manure fertilizer decreased number of infested faba bean plants/plot by $(33.41 \& 17.40)$ and $(13.86$ \& $10.58 \%$, number of spikes broomrape/plot by (31.49 \& 22.16\%) and (15.44 \& 12.83\%) and dry weight spikes (g/plot) of broomrape by (31.38 \& 22.00\%) and (15.45 \& 12.84\%) in 2016/17 and 2017/18 seasons, respectively, compared with non-fertilizer check.

Nitrogen fertilization at rate $20 \mathrm{~kg} / \mathrm{fed}$ and nitrogen fertilization at rate $10 \mathrm{~kg} / \mathrm{fed}$ +Organic manure fertilizers at rate 10 $\mathrm{m}^{3} / \mathrm{fed}$ gave the highest reduction incidence (10.27 \& 12.99\%) and (12.63 \& $13.17 \%)$ and severity $(0.13 \& 0.15 \%)$ and $(0.14 \& 0.15 \%)$ of broomrape as compared to non-fertilizer (15.65 \& $14.76 \%)$ and $(0.12 \& 0.18 \%)$ in $2016 / 17$ and $2017 / 18$ seasons, respectively.

This might be due to nitrogenous fertilizers reduced crenate broomrape seed germination and radicle length of germinated seeding. Nitrogen from different sources had different inhibitory 
effects. The effect could be due to a direct interaction with the metabolism of broomrapes by altering the osmotic balance (Ernst 1988), since high nitrogen supply would reduce the uptake of potassium (Welte and Wemer 1963) for which the parasite has a high demand (Ernst 1988). Also, several authors reported direct toxicity by nitrogen fertilizers to seeds of broomrape. These results are in line with those obtained by Van Hezewijk et al (1991), Demirkan and Nemli (1994), Nandula et al. (1996), Ismail (2013) and Fakkar et al (2016).

Organic manure fertilizer at $20 \mathrm{~m}^{3} / \mathrm{fed}$ decreased number of plant infestation/plot, number of broomrape spikes/plot and dry weight of broomrape spikes (g/plot) by $(8.37,16.36$ and $16.33 \%)$ in $2016 / 17$ season and by $(9.46$, 11.15 and $11.16 \%$ ) in $2017 / 18$ seasons, respectively, compared with non-fertilizer check. These results are in line with those obtained by Jain and Foy (1992).

\section{2- Yield and yield components of faba}

The data in Table (4) revealed that using fertilizers had significant influence on yield and yield components of faba in 2016/17 and 2017/18 seasons. Applied of $20 \mathrm{~kg} \mathrm{~N} / \mathrm{fed}$ and $\mathrm{N}$-fertilization at $10 \mathrm{~kg}$ /fed + O.M-fertilizers at $10 \mathrm{~m}^{3} / \mathrm{fed}$ recorded the highest values for plant height $(\mathrm{cm})$, number of branches/plant, number of pods/plant, weight of pods/plant (g), seed weight/plant (g), 100seed weight $(\mathrm{g})$ and seed yield/fed in both seasons compared with non-fertilizer.

Application of $\mathrm{N}$-fertilization and $\mathrm{N}$ fertilization + O.M-fertilizers significantly increased number of pods/plant by (35.41 \& $18.46 \%)$ and (11.15 \& $7.44 \%$ ), weight of pods/plant by (27.07 \& 11.07\%) and (18.61 \& $10.13 \%)$, seed weigh/plant by (30.98 \& $13.98 \%)$ and $(23.26 \& 13.23 \%)$, 100-seed weight by $(18.94 \& 10.54 \%)$ and $(14.78 \&$ $7.89 \%)$ and seed yield /fed.by (19.76 \& $15.42 \%)$ and (19.65 \& $16.70 \%)$ in $2016 / 17$ and 2017/18 seasons, respectively, as compared with non-fertilizer treatment.

Table (3): Effect of fertilizer on broomrape growth characters in 2016/17 and 2017/18 seasons

\begin{tabular}{|c|c|c|c|c|c|c|}
\hline $\begin{array}{l}\text { Broomrape control } \\
\text { treatments }\end{array}$ & $\begin{array}{c}\text { No. of faba } \\
\text { bean } \\
\text { plants/plot }\end{array}$ & $\begin{array}{c}\text { No. of } \\
\text { infested } \\
\text { faba bean } \\
\text { plants/plot }\end{array}$ & $\begin{array}{c}\text { No. of } \\
\text { broomrape } \\
\text { spikes /plot }\end{array}$ & $\begin{array}{c}\text { Weight of } \\
\text { broomrape } \\
\text { Spikes } \\
\text { /plot }\end{array}$ & $\begin{array}{c}\text { Incidence } \\
\%\end{array}$ & Severity \\
\hline & \multicolumn{6}{|c|}{ 2016/17 season } \\
\hline Nitrogen fertilization & 218.39 & 22.38 & 27.67 & 116.20 & 10.27 & 0.13 \\
\hline Organic manure fertilizers & 210.33 & 30.75 & 33.78 & 141.68 & 14.94 & 0.16 \\
\hline $\begin{array}{l}\text { Nitrogen + Organic } \\
\text { manure fertilizers }\end{array}$ & 215.89 & 27.72 & 31.44 & 132.07 & 12.99 & 0.15 \\
\hline Untreated (check) & 195.94 & 33.56 & 40.39 & 169.33 & 17.65 & 0.21 \\
\hline \multirow[t]{2}{*}{ L.S.D $D_{0.05}$} & 9.83 & 2.66 & 3.22 & 13.54 & 1.45 & 0.02 \\
\hline & \multicolumn{6}{|c|}{ 2017/18 season } \\
\hline Nitrogen fertilization & 211.39 & 26.22 & 30.72 & 129.03 & 12.63 & 0.14 \\
\hline Organic manure fertilizers & 207.89 & 27.56 & 32.28 & 135.57 & 13.36 & 0.16 \\
\hline $\begin{array}{l}\text { Nitrogen + Organic } \\
\text { manure fertilizers }\end{array}$ & 209.61 & 27.22 & 31.67 & 133.00 & 13.17 & 0.15 \\
\hline Untreated (check) & 205.39 & 30.44 & 36.33 & 152.60 & 14.76 & 0.18 \\
\hline L.S.D $D_{0.05}$ & 12.61 & 3.19 & 3.10 & 13.02 & 1.87 & 0.3 \\
\hline
\end{tabular}

${ }^{*}$ Plot area was $10.5 \mathrm{~m}^{2}$ 
Effect of glyphosate, salicylic acid, nitrogen and organic fertilization ...........

Table (4): Effect of fertilizer on yield and yield components of faba in 2016/17 and 2017/18 seasons

\begin{tabular}{|l|c|c|c|c|c|c|c|}
\hline $\begin{array}{c}\text { Broomrape control } \\
\text { treatments }\end{array}$ & $\begin{array}{c}\text { Plant } \\
\text { height } \\
\text { (cm) }\end{array}$ & $\begin{array}{c}\text { No .of } \\
\text { branches } \\
\text { / plant }\end{array}$ & $\begin{array}{c}\text { No. of } \\
\text { pods } \\
\text { / plant }\end{array}$ & $\begin{array}{c}\text { Weight } \\
\text { of pods } \\
\text { / plant }\end{array}$ & $\begin{array}{c}\text { Seed } \\
\text { weight } \\
\text { (g) / } \\
\text { plant }\end{array}$ & $\begin{array}{c}100- \\
\text { seeds } \\
\text { weight } \\
\text { (g) }\end{array}$ & $\begin{array}{c}\text { Seed } \\
\text { yield } \\
\text { (Ardab) } \\
\text { /fed. }\end{array}$ \\
\hline \multicolumn{7}{|c|}{$2016 / 17$ season } \\
\hline Nitrogen fertilization & 129.61 & 3.33 & 34.19 & 72.66 & 62.03 & 71.03 & 6.06 \\
\hline $\begin{array}{l}\text { Organic manure } \\
\text { fertilizers }\end{array}$ & 121.50 & 2.96 & 27.98 & 62.74 & 51.49 & 64.24 & 5.68 \\
\hline $\begin{array}{l}\text { Nitrogen + Organic } \\
\text { manure fertilizers }\end{array}$ & 123.75 & 3.20 & 29.91 & 63.51 & 53.98 & 66.07 & 5.84 \\
\hline Untreated (check) & 120.08 & 2.90 & 25.25 & 57.18 & 47.36 & 59.77 & 5.06 \\
\hline \multicolumn{1}{|c|}{ L.S.D $D_{0.05}$} & 2.83 & 0.18 & 1.71 & 2.78 & 3.18 & 2.65 & 0.23 \\
\hline \multicolumn{7}{|c|}{$2017 / 18$ season } \\
\hline Nitrogen fertilization & 127.27 & 3.65 & 28.82 & 67.22 & 61.04 & 69.11 & 6.09 \\
\hline $\begin{array}{l}\text { Organic manure } \\
\text { fertilizers }\end{array}$ & 121.67 & 3.13 & 26.19 & 60.34 & 51.75 & 61.76 & 5.54 \\
\hline $\begin{array}{l}\text { Nitrogen + Organic } \\
\text { manure fertilizers }\end{array}$ & 123.64 & 3.20 & 27.86 & 62.41 & 56.07 & 64.96 & 5.94 \\
\hline Untreated (check) & 119.34 & 2.96 & 25.93 & 56.67 & 49.52 & 60.21 & 5.09 \\
\hline \multicolumn{1}{|c|}{ L.S.D $D_{0.05}$} & 1.94 & 0.12 & 2.04 & 2.37 & 2.00 & 2.75 & 0.31 \\
\hline
\end{tabular}

Organic manure fertilizer at $30 \mathrm{~m}^{3} / \mathrm{fed}$. significantly increased number of pods/plant by $(10.81$ and $1.00 \%)$, weight of pods plant by $(9.72$ and $6.48 \%)$, seed weigh/plant by $(8.72$ and $4.50 \%)$, 100 seed weight by $(7.48$ and $2.57 \%)$ and seed yield/fed. by (12.25 and $8.84 \%)$ in 2016/17 and 2017/18 seasons, respectively, as compared without fertilizer. This may be due to the role of nitrogen fertilizer or organic manure in inhibitory effect on Broomrape, this will reflected on yield due its component of faba bean.

These results are in line with those obtained by Jain and Foy (1992), some researchers have reported that the addition of manure and nitrogenous fertilizers improved crop yields due to a detrimental effect of the fertilizers on the parasitic infestations, but others have attributed the beneficial effects of nitrogenous fertilization directly to improve crop performance and tolerance to attack by parasite. Similar results were reported by Nandula et al. (1996), Ismail (2013), Shaban et al. (2013) and Fakkar et al. (2016).

\section{B-Effect of broomrape control treatments: \\ 1- Broomrape}

Data in Table (5) indicated that broomrape control treatments significantly reduced broomrape characters compared with untreated control in 2016/17 and 2017/18 seasons.

Foliar application of Glyphosate (48\% WSC) at 2 times with equal rate 75 $\mathrm{cm}^{3} / \mathrm{fed}$ at the beginning of the flowering stage with 21 days interval between each 
one (T1), Salicylic acid thrice (T4) applied when faba bean germination is complete, at $\mathbf{3 0}$ days after planting and beginning of the flowering stage at rate $200 \mathrm{mg} / \mathrm{one}$ liter water solution of the corresponding compounds and Glyphosate used at one times with equal rate $75 \mathrm{~cm}^{3} / \mathrm{fed}$ (T2). at the beginning of the flowering stage followed by Salicylic acid once at 200 $\mathrm{mg} /$ one liter water at 30 days after planting increased significantly number plants of faba bean/plot but decreased no. of infested faba bean plants/plot, no. of broomrape spikes/plot and dry weight broomrape spikes/plot of broomrape compared with untreated in both seasons.

Foliar application of Glyphosate twice at $75 \mathrm{~cm}^{3} / \mathrm{fed}$ (T1) and Salicylic acid thrice at $200 \mathrm{mg} / \mathrm{one}$ liter water (T4) increased number plants of faba bean/plot by $(12.44 \& 12.35 \%)$ and $(4.61 \&$ $4.12 \%$ ) but decreased the number of faba bean plants/plot by ( $59.43 \& 46.69 \%)$ and (52.52 \& 51.54\%), number of broomrape spikes /plot by (55.06 \& $50.64 \%)$ and $(49.63 \& 49.48 \%)$ and dry weight broomrape spikes/plot by $(55.10 \&$ $50.69 \%)$ and $(49.62 \& 49.47 \%)$ in $2016 / 17$ and $2017 / 18$ seasons, respectively, as compared with untreated (T6) (control).

Table (5): Effect of broomrape control treatments on broomrape growth characters in 2016/17 and 2017/18 seasons

\begin{tabular}{|l|c|c|c|c|c|c|}
\hline \multicolumn{1}{|c|}{$\begin{array}{c}\text { Broomrape control } \\
\text { treatments }\end{array}$} & $\begin{array}{c}\text { No. of faba } \\
\text { bean plants } \\
\text { /plot }\end{array}$ & $\begin{array}{c}\text { No. of } \\
\text { infested } \\
\text { faba bean } \\
\text { plants } \\
\text { /plot }\end{array}$ & $\begin{array}{c}\text { No. of } \\
\text { broomrape } \\
\text { spikes } \\
\text { /plot }\end{array}$ & $\begin{array}{c}\text { Weight of } \\
\text { broomrape } \\
\text { Spikes } \\
\text { /plot }\end{array}$ & $\begin{array}{c}\text { Incidence } \\
\%\end{array}$ & Severity \\
\hline T1- Glyphosate twice 75 & 216.92 & 19.67 & 25.42 & 106.76 & 9.61 & 0.12 \\
\hline $\begin{array}{l}\text { T2- Glyphosate once } \\
\text { 75+ Salicylic acid once }\end{array}$ & 216.58 & 25.68 & 29.50 & 123.90 & 11.86 & 0.14 \\
\hline $\begin{array}{l}\text { T3- Glyphosate once } \\
\text { 50+ Salicylic acid once }\end{array}$ & 210.25 & 25.67 & 29.75 & 124.95 & 12.34 & 0.14 \\
\hline T4- Salicylic acid thrice & 216.75 & 24.34 & 27.92 & 117.23 & 11.21 & 0.13 \\
\hline T5-Hand pulling twice & 207.42 & 26.16 & 30.75 & 126.15 & 12.28 & 0.14 \\
\hline T6- Untreated (chick) & 192.92 & 48.38 & 56.58 & 237.75 & 26.47 & 0.30 \\
\hline L.S.D 0.05 & 6.38 & 3.34 & 4.41 & 18.52 & 1.78 & 0.03 \\
\hline & & & $2017 / 18$ Winter season \\
\hline T1- Glyphosate twice 75 & 211.58 & 22.83 & 27.58 & 115.85 & 10.90 & 0.13 \\
\hline $\begin{array}{l}\text { T2- Glyphosate once } \\
\text { 75+ Salicylic acid once }\end{array}$ & 210.58 & 23.75 & 28.25 & 118.65 & 11.77 & 0.14 \\
\hline $\begin{array}{l}\text { T3- Glyphosate once } \\
\text { 50+ Salicylic acid once }\end{array}$ & 21017 & 24.58 & 28.75 & 120.75 & 11.75 & 0.14 \\
\hline T4- Salicylic acid thrice & 210.58 & 23.33 & 27.66 & 116.20 & 11.07 & 0.12 \\
\hline T5-Hand pulling twice & 206.25 & 24.58 & 29.50 & 123.90 & 11.54 & 0.14 \\
\hline T6- Untreated (chick) & 202.25 & 48.08 & 54.75 & 229.95 & 23.85 & 0.27 \\
\hline L.S.D 0.05 & 9.38 & 3.05 & 3.37 & 13.72 & 1.74 & 0.02 \\
\hline
\end{tabular}


Foliar application of Glyphosate twice at $75 \mathrm{~cm}^{3} / \mathrm{fed}$ (T1) and Salicylic acid thrice at $200 \mathrm{mg} / \mathrm{one}$ liter water (T4) gave the lowest incidence by $(9.610 \& 11.21 \%)$ and $(10.90 \& 11.07 \%)$ and severity $(0.12 \&$ $0.13 \%)$ and $(0.13 \& 0.12 \%)$, respectively, of broomrape as compared to untreated in both seasons. Hand pulling twice (T5) gave the lowest values number plants of faba bean $/ \mathrm{m}^{2}$, no. of plant of faba bean infestation, no. of broomrape spikes /plot and dry weight broomrape spikes/plot of broomrape at compared with untreated in both seasons.

This effect due to Glyphosate treatment with broomrape underground stage, so it makes early effects, while, the effect of hand pulling is usually after broomrape emergence above ground. These results are in agreement with those of Kharrat and Halila (1999) and Bakheit et al. (2001). Abbes et al (2014) demonstrate that (SAR) is capable of being an important method to control broomrapes and to form an integrated control strategy leading to reduce soil infestation by Orobanche.

\section{2- Yield and yield components of faba}

Data recorded in Table (6) revealed broomrape control treatments significantly differed yield and yield components in both seasons.

Foliar application of Glyphosate twice at $75 \mathrm{~cm}^{3} / \mathrm{fed}(\mathrm{T} 1)$, Salicylic acid thrice at $200 \mathrm{mg} / \mathrm{one}$ liter water (T4) and Glyphosate once at $75 \mathrm{~cm}^{3} / \mathrm{fed}+$ Salicylic acid once at $200 \mathrm{mg} / \mathrm{one}$ liter water (T2) gave the highest values of plant height (cm), number of branches/plant, number of pods/plant, weight of pods/plant (g), seed weight/plant (g) and seed yield /fed. than glyphosate once at $50 \mathrm{~cm}^{3} / \mathrm{fed}+$ Salicylic acid once at $200 \mathrm{mg} / \mathrm{one}$ liter water at $\mathbf{3 0}$ days after planting and hand pulling twice (T5) compared with untreated (T6) (control)in both seasons.
Foliar application of Glyphosate twice at $75 \mathrm{~cm}^{3} / \mathrm{fed}$ (T1) Salicylic acid thrice at $200 \mathrm{mg} / \mathrm{one}$ liter water (T4) significant by increased number of pods/plant by (39.86 \& $33.96 \%)$ and (16.89 \& $16.18 \%$ ), weight of pods plant by (22.53 \& 19.12\%) and (17.19 \& $15.29 \%)$, seed weigh/plant by (25.54 \& $24.40 \%)$ and $(20.07 \& 18.23 \%), 100$-seed weight by (31.18 \& $28.77 \%)$ and $(5.77 \&$ $4.04 \%)$ and seed yield by $(73.82 \&$ $72.42 \%)$ and $(72.40 \& 70.19 \%)$ in $2016 / 17$ and 2017/18 seasons, respectively, as compared with non-fertilizer.

Foliar application of Glyphosate once at $75 \mathrm{~cm}^{3} / \mathrm{fed}$ + Salicylic acid once at 200 $\mathrm{mg} /$ one liter water (T2) and Glyphosate once at $50 \mathrm{~cm}^{3} / \mathrm{fed}$ + Salicylic acid once at $200 \mathrm{mg} / \mathrm{one}$ liter water (T3) increased number of pods/plant by (27.79 \& $25.29 \%)$ and (15.44 \& $14.48 \%$ ), weight of pods plant by (15.24 \& $14.55 \%)$ and $(14.53 \&$ $13.76 \%)$, seed weigh/plant by $(23.60 \&$ $20.38 \%)$ and (17.17 \& 13.15\%), 100-seed weight by $(28.47 \& 27.32 \%)$ and $(3.05 \&$ $2.64 \%)$ and seed yield /fed by $(71.87 \&$ $69.92 \%)$ and $(69.64 \& 69.36 \%)$ in $2015 / 16$ and 2016/17 seasons, respectively, as compared with non-fertilizer. Hand pulling twice (T5) increased number of pods/plant by (22.78 \& 14.9\%), weight of pods plant by $(11.81 \& 13.50 \%)$, seed weigh/plant by (10.23 and $9.82 \%), 100$ seed weight by $(21.17 \& 1.05 \%)$ and seed yield /fed. by (63.79 \& 64.90\%) in 2016/17 and 2017/18 seasons, respectively, as compared with non-fertilizer.

This increase of faba bean seed yield may be due to the increase in number of pods/plant, weight of pods/plant (g), seed weight/plant $(\mathrm{g})$ and the decrease of number and dry weight of broomrape spikes. These results are in agreement with those of Ismail and Fakkar (2008), Bayoumi et al (2013), Ismail (2013), Fakkar et al (2013), El-Metwally et al (2013), Abbes et al (2014), El-Rokiek et al (2015) and Fakkar et al (2016). 
S.H.M. Abd-El-Haleem, et al.,

Table (6): Effect of broomrape control treatments on yield and yield components of faba bean in 2016/17 and 2017/18 seasons.

\begin{tabular}{|c|c|c|c|c|c|c|c|}
\hline $\begin{array}{l}\text { Broomrape control } \\
\text { treatments }\end{array}$ & $\begin{array}{c}\text { Plant } \\
\text { height }(\mathrm{cm})\end{array}$ & $\begin{array}{c}\text { No. of } \\
\text { branches } \\
\text { /plant }\end{array}$ & $\begin{array}{c}\text { No. of } \\
\text { pods / } \\
\text { plant } \\
(g)\end{array}$ & $\begin{array}{l}\text { Weight } \\
\text { of pods } \\
\text { / plant } \\
\text { (g) }\end{array}$ & \begin{tabular}{|c} 
Seed \\
weight $/$ \\
Plant \\
$(g)$
\end{tabular} & $\begin{array}{c}\text { 100- } \\
\text { seeds } \\
\text { Weight } \\
\text { (g) }\end{array}$ & $\begin{array}{c}\text { Seed } \\
\text { yield / } \\
\text { fed } \\
\text { (ardab). }\end{array}$ \\
\hline & \multicolumn{7}{|c|}{2016 / 17 Winter season } \\
\hline T1- Glyphosate twice 75 & 131.55 & 3.55 & 32.91 & 68.97 & 57.46 & 69.72 & 6.24 \\
\hline $\begin{array}{l}\text { T2- Glyphosate once } 75+ \\
\text { Salicylic acid once }\end{array}$ & 126.74 & 3.42 & 30.07 & 64.87 & 56.57 & 68.28 & 6.17 \\
\hline $\begin{array}{l}\text { T3- Glyphosate once } 50+ \\
\text { Salicylic acid once }\end{array}$ & 124.32 & 3.21 & 29.48 & 64.48 & 55.10 & 67.67 & 6.10 \\
\hline T4- Salicylic acid thrice & 126.67 & 3.46 & 31.52 & 67.05 & 56.94 & 68.44 & 6.19 \\
\hline T5-Hand pulling twice & 123.67 & 3.15 & 28.89 & 62.94 & 50.45 & 64.40 & 5.88 \\
\hline T6- Untreated (chick) & 109.45 & 1.86 & 23.53 & 56.29 & 45.77 & 53.15 & 3.59 \\
\hline \multirow[t]{2}{*}{ L.S.D 0.05} & 2.54 & 0.18 & 2.14 & 3.55 & 3.35 & 2.78 & 0.24 \\
\hline & \multicolumn{7}{|c|}{2017 / 18 Winter season } \\
\hline T1- Glyphosate twice 75 & 126.11 & 3.62 & 28.17 & 64.30 & 57.97 & 67.60 & 6.19 \\
\hline $\begin{array}{l}\text { T2- Glyphosate once } 75+ \\
\text { Salicylic acid once }\end{array}$ & 125.29 & 3.43 & 27.82 & 62.84 & 56.57 & 65.86 & 6.09 \\
\hline $\begin{array}{l}\text { T3- Glyphosate once } 50+ \\
\text { Salicylic acid once }\end{array}$ & 125.20 & 3.34 & 27.59 & 62.42 & 54.63 & 65.60 & 6.08 \\
\hline T4- Salicylic acid thrice & 127.27 & 3.52 & 28.00 & 63.26 & 57.08 & 66.49 & 6.11 \\
\hline T5-Hand pulling twice & 122.10 & 3.41 & 27.52 & 62.28 & 53.02 & 64.58 & 5.92 \\
\hline T6- Untreated (chick) & 112.06 & 2.18 & 24.10 & 54.87 & 48.28 & 63.91 & 3.59 \\
\hline L.S.D 0.05 & 2.82 & 0.23 & 1.95 & 2.55 & 2.43 & 2.51 & 0.29 \\
\hline
\end{tabular}

\section{C-Interactions}

1-Effect of interactions between fertilizer and broomrape control treatments on broomrape.

Data in Table (7) showed that the effects of interactions between fertilizer and broomrape control treatments on broomrape were statistically significant at (0.05) in 2016/17 and 2017/18 seasons.

The effect of interaction between fertilizer and broomrape control treatments on no.of plant infection/plot, number of broomrape spikes (plot) incidence $\%$ and severity $\%$ were statistically significant at (0.05) level except for number of plants faba bean/plot and weight of broomrape spikes (g/plot) in both seasons.

The highest reduction incidence of broomrape optioned by $\mathrm{N}$-fertilizer at 20 $\mathrm{kg} / \mathrm{fed}$ and $\mathrm{N}$-fertilizer at $10 \mathrm{~kg} / \mathrm{fed}+\mathrm{O} . \mathrm{M}$ fertilizer at $10 \mathrm{~m}^{3} / \mathrm{fed}$ under Glyphosate twice $75 \mathrm{~cm}^{3} / \mathrm{fed}$ and Salicylic acid thrice in both seasons. These results demonstrate the role of integration between N-fertilizer, agricultural, mechanical and chemical methods in controlling broomrape in faba bean. Hand 
Effect of glyphosate, salicylic acid, nitrogen and organic fertilization

pulling and herbicide in these results is very clear and effective. These results are in good harmony with those reported by Mekky et al. (2003), Khalil et al. (2010),
Kawochar et al. (2011), El-Metwally et al. (2013), Fakkar et al (2013), El-Rokiek et al (2015) and Fakkar et al (2016).

Table (7): Effect of interaction between fertilizer and broomrape control treatments on broomrape growth characters in $2016 / 17$ and $2017 / 18$ seasons.

\begin{tabular}{|c|c|c|c|c|c|c|c|c|c|}
\hline \multirow[t]{2}{*}{ Fertilizer } & \multirow[t]{2}{*}{$\begin{array}{l}\text { Broomrape control } \\
\text { treatments }\end{array}$} & \multicolumn{2}{|c|}{$\begin{array}{c}\text { No. of } \\
\text { infested } \\
\text { faba bean } \\
\text { plants/plot }\end{array}$} & \multicolumn{2}{|c|}{$\begin{array}{c}\text { No. of } \\
\text { broomrape } \\
\text { spikes/plot }\end{array}$} & \multicolumn{2}{|c|}{$\begin{array}{c}\text { Incidence } \\
\%\end{array}$} & \multicolumn{2}{|c|}{ Severity } \\
\hline & & $\begin{array}{c}2016 / \\
17 \\
\end{array}$ & $\begin{array}{c}2017 / \\
18\end{array}$ & $\begin{array}{c}2016 / \\
17 \\
\end{array}$ & $\begin{array}{c}2017 / \\
18\end{array}$ & $\begin{array}{c}2016 / \\
17\end{array}$ & $\begin{array}{c}2017 / \\
18 \\
\end{array}$ & $\begin{array}{c}2016 / \\
17\end{array}$ & $\begin{array}{c}2017 / \\
18 \\
\end{array}$ \\
\hline \multirow{6}{*}{$\begin{array}{l}\text { Nitrogen } \\
\text { fertilization }\end{array}$} & 1- Glyphosate twice 75 & 15.00 & 21.00 & 19.67 & 24.67 & 6.70 & 9.77 & 0.08 & 0.11 \\
\hline & $\begin{array}{l}\text { 2- Glyphosate 75+ } \\
\text { Salicylic acid }\end{array}$ & 19.67 & 21.33 & 24.33 & 26.33 & 9.26 & 11.87 & 0.11 & 0.13 \\
\hline & $\begin{array}{l}\text { 3- Glyphosate 50+ } \\
\text { Salicylic acid }\end{array}$ & 20.33 & 23.33 & 26.00 & 27.33 & 9.27 & 12.07 & 0.12 & 0.14 \\
\hline & 4- Salicylic acid thrice & 18.33 & 21.33 & 23.33 & 26.00 & 8.60 & 10.23 & 0.10 & 0.12 \\
\hline & 5-Hand pulling twice & 21.33 & 23.67 & 26.33 & 27.00 & 9.40 & 12.63 & 0.12 & 0.14 \\
\hline & 6- Untreated (chick) & 39.67 & 46.67 & 46.33 & 53.00 & 18.40 & 22.43 & 0.21 & 0.26 \\
\hline \multirow{6}{*}{$\begin{array}{c}\text { Organic } \\
\text { manure } \\
\text { fertilizers }\end{array}$} & 1- Glyphosate twice 75 & 17.04 & 21.33 & 21.33 & 23.33 & 8.43 & 9.07 & 0.10 & 0.12 \\
\hline & $\begin{array}{l}\text { 2- Glyphosate 75+ } \\
\text { Salicylic acid }\end{array}$ & 27.02 & 25.00 & 29.33 & 28.00 & 10.66 & 11.07 & 0.14 & 0.13 \\
\hline & $\begin{array}{l}\text { 3- Glyphosate 50+ } \\
\text { Salicylic acid }\end{array}$ & 27.39 & 25.67 & 31.34 & 28.33 & 11.77 & 1160 & 0.15 & 0.14 \\
\hline & 4- Salicylic acid thrice & 25.04 & 21.67 & 28.67 & 27.67 & 10.60 & 10.87 & 0.13 & 0.13 \\
\hline & 5-Hand pulling twice & 33.67 & 26.00 & 32.33 & 30.67 & 12.71 & 13.40 & 0.16 & 0.14 \\
\hline & 6- Untreated (chick) & 54.33 & 45.67 & 59.67 & 55.67 & 23.77 & 24.17 & 0.32 & 0.26 \\
\hline \multirow{6}{*}{$\begin{array}{c}\text { Nitrogen } \\
\text { fertilization } \\
+ \text { Organic } \\
\text { manure } \\
\text { fertilizers }\end{array}$} & 1- Glyphosate twice 75 & 18.33 & 19.33 & 22.33 & 24.67 & 7.87 & 9.90 & 0.10 & 0.11 \\
\hline & $\begin{array}{l}\text { 2- Glyphosate 75+ } \\
\text { Salicylic acid }\end{array}$ & 23.67 & 23.00 & 26.67 & 28.33 & 12.21 & 10.27 & 0.12 & 0.13 \\
\hline & $\begin{array}{l}\text { 3- Glyphosate } 50+ \\
\text { Salicylic acid }\end{array}$ & 26.33 & 23.67 & 28.33 & 29.67 & 12.53 & 11.16 & 0.13 & 0.14 \\
\hline & 4- Salicylic acid thrice & 22.33 & 22.67 & 26.00 & 25.00 & 11.81 & 10.10 & 0.11 & 0.13 \\
\hline & 5-Hand pulling twice & 27.67 & 23.67 & 29.33 & 30.33 & 16.30 & 11.17 & 0.13 & 0.16 \\
\hline & 6- Untreated (chick) & 48.00 & 48.33 & 56.00 & 52.00 & 28.90 & 23.17 & 0.28 & 0.28 \\
\hline \multirow{6}{*}{$\begin{array}{l}\text { Untreated } \\
\text { (check) }\end{array}$} & 1- Glyphosate twice 75 & 23.33 & 24.67 & 30.33 & 30.00 & 11.60 & 11.80 & 0.15 & 0.14 \\
\hline & $\begin{array}{l}\text { 2- Glyphosate 75+ } \\
\text { Salicylic acid }\end{array}$ & 29.33 & 25.67 & 35.33 & 30.66 & 15.47 & 12.47 & 0.18 & 0.15 \\
\hline & $\begin{array}{l}\text { 3- Glyphosate 50+ } \\
\text { Salicylic acid }\end{array}$ & 33.33 & 26.00 & 40.33 & 33.00 & 15.53 & 12.77 & 0.18 & 0.16 \\
\hline & 4- Salicylic acid thrice & 23.67 & 25.65 & 31.67 & 30.67 & 12.87 & 12.33 & 0.17 & 0.15 \\
\hline & 5-Hand pulling twice & 34.00 & 29.00 & 40.67 & 35.33 & 15.63 & 13.57 & 0.19 & 0.16 \\
\hline & 6- Untreated (chick) & 57.33 & 51.67 & 64.33 & 58.33 & 34.80 & 25.63 & 0.39 & 0.29 \\
\hline L.S.D $D_{0.05}$ & & 6.68 & 6.10 & 8.82 & 6.53 & 3.57 & 3.22 & 0.05 & 0.04 \\
\hline
\end{tabular}




\section{2- Interaction between manure and} broomrape control treatments on yield of faba bean:

The effects of interaction between fertilizer and broomrape control treatments were statistically significant on yield and yield components in both seasons except for plant height, n.of pods/plant and weight of pods/plants in both seasons. Using of $\mathrm{N}$-fertilizer at 20 $\mathrm{kg} / \mathrm{fed}$ and $\mathrm{N}$-fertilizer at $10 \mathrm{~kg} / \mathrm{fed}+0 . \mathrm{M}$ fertilizer at $10 \mathrm{~m}^{3} / \mathrm{fed}$ under glyphosate twice $75 \mathrm{~cm}^{3} / \mathrm{fed}$ and Salicylic acid thrice gave the highest values number of branches/plant, number of pods/plant, weight of pods/plant (g), seed weight/plant ( $g$ ) and seed yield /fed. in both seasons (Table 8).

Table (8): Effect of interaction between fertilizer and broomrape control treatments on yield and yield components of faba bean in $2016 / 17$ and $2017 / 18$ seasons.

\begin{tabular}{|c|c|c|c|c|c|c|c|c|c|}
\hline \multirow[t]{2}{*}{ Fertilizer } & \multirow{2}{*}{$\begin{array}{l}\text { Broomrape control } \\
\text { treatments }\end{array}$} & \multicolumn{2}{|c|}{$\begin{array}{c}\text { No. of } \\
\text { branches/plant }\end{array}$} & \multicolumn{2}{|c|}{$\begin{array}{c}\text { Weight of } \\
\text { seeds/plant } \\
\text { (g) }\end{array}$} & \multicolumn{2}{|c|}{$\begin{array}{l}\text { 100-seeds } \\
\text { Weight (g) }\end{array}$} & \multicolumn{2}{|c|}{$\begin{array}{l}\text { Seed yield } \\
\text { (ardab)/fed. }\end{array}$} \\
\hline & & $\begin{array}{c}2016 / \\
17\end{array}$ & $\begin{array}{c}2017 / \\
18\end{array}$ & $\begin{array}{c}2016 / \\
17\end{array}$ & $\begin{array}{c}2017 / \\
18\end{array}$ & $\begin{array}{c}2016 / \\
17\end{array}$ & $\begin{array}{c}2017 / \\
18\end{array}$ & $\begin{array}{c}2016 / \\
17\end{array}$ & $\begin{array}{c}2017 / \\
18\end{array}$ \\
\hline \multirow{6}{*}{$\begin{array}{l}\text { Nitrogen } \\
\text { fertilization }\end{array}$} & 1- Glyphosate twice 75 & 4.10 & 3.94 & 67.63 & 64.33 & 74.50 & 73.17 & 6.87 & 6.66 \\
\hline & $\begin{array}{l}\text { 2- Glyphosate 75+ } \\
\text { Salicylic acid }\end{array}$ & 3.47 & 3.89 & 63.70 & 62.53 & 74.13 & 72.00 & 6.27 & 6.17 \\
\hline & $\begin{array}{l}\text { 3- Glyphosate 50+ } \\
\text { Salicylic acid }\end{array}$ & 3.36 & 3.81 & 63.43 & 62.10 & 73.27 & 71.00 & 6.17 & 6.07 \\
\hline & 4- Salicylic acid thrice & 3.51 & 3.91 & 64.30 & 64.07 & 74.37 & 72.50 & 6.80 & 6.60 \\
\hline & 5-Hand pulling twice & 3.34 & 3.79 & 61.73 & 61.10 & 72.07 & 70.27 & 5.90 & 5.70 \\
\hline & 6- Untreated (chick) & 2.19 & 2.59 & 51.43 & 52.13 & 57.87 & 55.70 & 4.53 & 4.33 \\
\hline \multirow{6}{*}{$\begin{array}{c}\text { Organic } \\
\text { manure } \\
\text { fertilizers }\end{array}$} & 1- Glyphosate twice 75 & 3.78 & 3.63 & 57.90 & 57.27 & 71.77 & 66.30 & 6.80 & 6.30 \\
\hline & $\begin{array}{l}\text { 2- Glyphosate 75+ } \\
\text { Salicylic acid }\end{array}$ & 3.42 & 3.38 & 54.50 & 52.87 & 66.96 & 64.30 & 6.33 & 5.90 \\
\hline & $\begin{array}{l}\text { 3- Glyphosate 50+ } \\
\text { Salicylic acid }\end{array}$ & 3.38 & 3.17 & 52.97 & 50.60 & 66.50 & 64.13 & 6.17 & 5.90 \\
\hline & 4- Salicylic acid thrice & 3.74 & 3.44 & 56.03 & 55.60 & 68.77 & 46.47 & 6.40 & 6.03 \\
\hline & 5-Hand pulling twice & 3.18 & 3.01 & 51.73 & 48.17 & 65.70 & 60.00 & 6.13 & 5.83 \\
\hline & 6- Untreated (chick) & 1.73 & 2.13 & 50.73 & 46.00 & 56.70 & 51.33 & 3.50 & 3.27 \\
\hline \multirow{6}{*}{$\begin{array}{c}\text { Nitrogen } \\
\text { fertilization+ } \\
\text { Organic } \\
\text { manure } \\
\text { fertilizers }\end{array}$} & 1- Glyphosate twice 75 & 3.85 & 3.75 & 56.91 & 59.66 & 72.43 & 69.03 & 6.46 & 6.80 \\
\hline & $\begin{array}{l}\text { 2- Glyphosate } 75+ \\
\text { Salicylic acid }\end{array}$ & 3.13 & 3.44 & 56.42 & 58.27 & 68.81 & 65.87 & 6.27 & 6.33 \\
\hline & $\begin{array}{l}\text { 3- Glyphosate 50+ } \\
\text { Salicylic acid }\end{array}$ & 3.08 & 3.43 & 49.63 & 55.37 & 68.27 & 65.70 & 6.07 & 6.17 \\
\hline & 4- Salicylic acid thrice & 3.21 & 3.47 & 56.71 & $59 . .03$ & 69.01 & 67.67 & 6.30 & 6.40 \\
\hline & 5-Hand pulling twice & 2.78 & 3.08 & 45.95 & 53.47 & 56.81 & 65.63 & 5.70 & 6.13 \\
\hline & 6- Untreated (chick) & 1.73 & 2.03 & 43.30 & 50.60 & 50.13 & 55.83 & 3.27 & 3.80 \\
\hline \multirow{6}{*}{$\begin{array}{l}\text { Untreated } \\
\text { (check) }\end{array}$} & 1- Glyphosate twice 75 & 3.86 & 3.64 & 53.53 & 53.90 & 66.47 & 63.27 & 5.83 & 5.63 \\
\hline & $\begin{array}{l}\text { 2- Glyphosate } 75+ \\
\text { Salicylic acid }\end{array}$ & 3.04 & 3.05 & 50.00 & 53.20 & 61.47 & 61.13 & 5.53 & 5.33 \\
\hline & $\begin{array}{l}\text { 3- Glyphosate 50+ } \\
\text { Salicylic acid }\end{array}$ & 2.77 & 2.92 & 49.28 & 51.23 & 60.17 & 61.07 & 5.37 & 5.17 \\
\hline & 4- Salicylic acid thrice & 3.47 & 3.33 & 52.57 & 53.27 & 64.43 & 62.37 & 5.77 & 5.57 \\
\hline & 5-Hand pulling twice & 2.75 & 2.84 & 41.13 & 44.40 & 58.20 & 60.63 & 5.27 & 5.07 \\
\hline & 6- Untreated (chick) & 1.78 & 1.96 & 37.63 & 41.13 & 47.90 & 52.77 & 2.77 & 2.57 \\
\hline \multicolumn{2}{|l|}{ L.S.D. $D_{0.05}$} & 0.36 & 0.47 & 5.42 & 4.77 & 5.56 & 5.02 & 0.49 & 0.57 \\
\hline
\end{tabular}


This may be owing to effect of interaction between the role of fertilizer with mechanical and chemical methods in controlling broomrape in faba bean. This may be due to the few amount of $\mathrm{N}$ in the organic manure than in synthetic nitrogenous fertilizers. These results are in good harmony with those reported by Mekky et al. (2003), Kawochar et al. (2011) and El-Metwally et al. (2013).

\section{CONCLUSION}

It can be concluded from this study that the feasibility of using cultural methods as mineral nitrogen and organic manure fertilizations beside foliar application of herbicide namely Glyphosate and/or Salicylic acid is considered a save method to broomrape control and increasing faba bean productivity in Upper Egypt.

\section{REFERANCES}

Abbes, Z, M. Mkadmi, Trabelsi, M. Amri and $M$. Kharrat (2014). Orobanche foetida control in faba bean by foliar application of benzothiadiazole (BTH) and Salicylic acid. Bulgarian Journal of Agricultural Science, vol. 20, no. 6: $1439-1443$.

Aftab, T., M. M. A. Khan, M. Idrees and M. Naeem Moinuddin (2010). Salicylic acid acts as potent enhancer of growth, photosynthesisand artemisinin production in Artemisia annua L. J. Crop. Sci. Biotech.3: 183188.

Al-Marsafy, H.T., E.E. Hassanein, A.N. Nassar and A.A. Fakkar (2001). Feasibility of Orobanche hand pulling in faba bean fields as an alternative or as a complement to chemical control. Nile Valley program for wild oats and other weeds control in winter cereals and some other winter crops. $9^{\text {th }}$ Ann. Coord. Meet. 2- 6 Sept. Cairo, Egypt. P.P. 282-285.
Anonymous (1994). Demonstration Book for Faba Bean Cultivation. Ministry of Agriculture, A.R.E. 39 pp. (In Arabic).

Bakheit, B. R., A. Y. Allam and A. H. Galal (2001). Intercropping faba bean with some legume crops for control of Orobanche crenata. Assiut J. of Agric, Sci., Vol. 32(3):1-9.

Bayoumi, T.Y., Sh. M. Ammar, M.A. S. ElBramawy and M.A. Emam (2013). Effect of Some Broornrape Control Methods on Growth and Seed Yield Attributes of Faba Bean (Vicia Faba L.) Cultivars. Journal of Plant Production Sciences; Suez Canal Uni. Volume (1): 17-24.

Demirkan, H. and Y. Nemli (1994). Effects of some fertilizers on Orobanche ramosa L. on tomato. Pages 499-501 in A. H. Pieterse, J.A.C. Verkleij, and S. J. ter Borg, eds. Proceedings of the Third International Work-shop on Orobanche and Related Striga Research. Amsterdam, The Netherlands: Royal Tropical Institute.

Eid, S. D. M., O. M. M. Mobarak and Kh. A. Abou-Zied (2017). Evaluation of Integrated Broomrape (Orobanche crenata) Management Packages under Effect of Varieties, Seeding Rates and Roundup Treatment in Faba Bean under Sandy Soil Conditions. Alex. J. Agric. Vol 62, no (1): 31-44.

EL-Metwally, I.M., T.A. El-Shahawy and M.A. Ahmed (2013). Effect of sowing dates and some broomrape control treatments on faba bean growth and yield. J. Appl., Sci. Res., 9 (1): 197-204.

Ernst, W. H. 0. (1988). Mineral nutrition of Nicotiana tabacum cv. Bursana during infection by Orobanche ramosa. Pages $\mathbf{8 0 - 8 5}$ in S. L. Borg, ter ed. Proceedings of a workshop on biology and control of Orvbanche. LH/VPO, Wageningen, the Netherlands.

EL-Rokiek, K.G., I.M. EL-Metwally, N.K. Messina and S.E.D.S. Amin (2015). Controlling orobanche crenata in faba bean using the herbicides glyphosate 
and imazapic with some additives, 1nternational journal, Agri. Research Vol.8, no.10 pp 18-26.

Fakkar, A.A.O., H. E.A. Ibrahim and M. A. Raslan (2016). Effect of sowing date, fertilizer and broomrape control treatments on faba bean (Vicia faba L.) productivity. Bull. Fac. Agric., Cairo Univ. 67:181-191.

Gonsior, G., H. Buschmann, G. Szinicz, S. Otmar and J. Sauerborn (2004). Induced resistance an innovative approach to manage branched broomrape (Orobanche ramosa) in hemp and tobacco. Weed Science, 52: 1050-1053.

Gorlach, J., S. Volrath, G. Knauf-Beiter, G. Hengy, U. Beckhove, K. H. Kogel, M. Oostendorp, T. Staub, E. Ward, H. Kessmann and J. Ryals (1996). Benzothiadiazole, a novel class of inducers of systemic acquired resistance, activates gene expression and disease resistance in wheat. The Plant Cell, 8: 629-643.

Ismail, A.E.A and A.A.O. Fakkar (2008). Faba bean yield losses due to Orobanche infestation and effect of plant density and weed control on annual weeds and Orobanche and faba bean productivity. Minia J. Agric. Res. Develop. Vol. 28, no. 4: 627-246.

Ismail, A.E.A. (2013). Integration between nitrogen, manure fertilizers, cultural practices and glyphosate on broomrape (Orobance crenata Forsk) control in faba beans (Vicia faba L.). Bull. Fac. Agric., Cairo Univ.vol. 64 no.4: 369- 378.

Jain, R. and C. L. Foy (1992). Nutrient effects on parasitism and germi-nation of Egyptian broomrape (Orobanche aegyptiaca). Weed Technol. 6: 269275.

Kawochar, M.A., M.J. Ullah, M.A. Salam, K.H. Alam and M.R. Islam (2011). Effect of sowing time and fertilizer on growth attributes, dry matter partitioning and grain yield of faba bean. J. Expt. Biosci., 2 (2): 17-24.

Kharrat, M. and M. H. Halila (1999). Control of Orobanche foetida on vicia faba: comparison between different control measures. Pages 734-738in Advances in Parasitic plant research (Junta de Andalucia, ed.).

Kharrat, M. and M.H. Halila (1996). Evaluation d'autres moyens de lutte contre Orbanche foetida Poir. Sur ficia faba L.pages 259-264 in Advances in Prasitic Weed Control at On-farm level. Joint action to control Orobanche in the WANA region. Vol. II (Kroshel J., Abdelrabibhi M., Betz H., eds.), du 30 Mars au 2 avril 1998 Proceeding de l'atelier tenu à Rabat, Morac.

Kusumoto, D., Y. Goldwasser, X. Xie, K. Yoneyama, Y. Takeuchi and K. Yoneyama (2007). Resistance of red clover (Trifolium pratense) to the root parasitic plant Orobanche minor is activated by salicylate but not jasmonate. Annals of Botany, 100:537544.

Luque, A., J.V. Jorrfn and D. Rubiales (2004). Crenate Broomrape Control in Pea by Foliar Application of Benzothiadiazole Phytoparasitica 32(1):21-29.

Nandula, V. K., C. L. Foy and J. H. Westwood (1996). Environmental influences on germination of Orobanche. Pages 409-416 in M. T. Moreno, J. I. Cubero, D. Berner, D. Joel, and L. J. Musselman, eds. Advances in Parasitic Plant Research. Cordoba, Spain: Junta de An-dalucia.

Mekky, M.S., Z.R. Yehia and A.N.M. Nassar (2003). Effect of sowing date, varieties and glyphosate application on broomrape and yield of faba bean. Bull. Fac. Agric. Cairo; Univ., 54: 55-76

Pieterse, A. H. (1991). The effect of nitrogen fertilizers on the germination of seeds of Striga hermonthica and 
Orobanche crenata. Pages1 15-124 in K. Wegmann and L. J. Musselman, eds. 1991. Progress in Orobanche Research. Eberhard-Karls-Universitat, Tu bengen, F RG.

Saxena, M. C., K.H. Linke and J. Sauerborn (1994). Integrated control of Ombanche in cool-season food legumes. In: A. H. Pieterse, J. A. C. Verkleij and S. J. Terborg (eds.). Biology and management of Ombanche. Proceedings of the Third International Workshop on Ombanche and related Striga research, pp. 419431.

Snedecor, G. and W. G. Cochran (1981). "Statistical Methods"7th ed. lowa State Univ., Ames, lowa, USA.

Shaban, S.H.A., A.H. El-Hattab, A. Esmat and M.R. Abo El-Suoud (2013). Recovery of faba bean (Vicia faba L.) plants as affected by glyphosate. J. Agron. and Crops Sci. 158: 294- 303.
Van, Hezewijk M. J., K. H. Linke, J.A.C. Verkleij and A. H. Pieterse (1991). The effect of ammonium fertilizer in combination with nitrification inhibitors on Orobanche crenata infestation in faba bean. Pages 470483 in J. K. Ransom, L. J. Musselman, A. D. Worsham, and C. Parker, eds. Proceedings of the Fifth International Symposium on Par-asitic Weeds. Nairobi, Kenya: CIMMYT.

Ward, E. R., S. J. Uknes, S. C. William, S. S. Dincher, D. L. Wiederhold, D. C. Alexander, P. Ahl-Goy, J. P. Métraux and J. Ryals (1991). Coordinate gene activation in response to agents that induce systemic acquired resistance. Plant Cell, 3: 1085-1094.

Welte, E. and W. Werner (1963). Potassium-magnesium antagonism in soil and crops. J. Sci. Food Agric. L4: 180-186. 
تاثير الجليفوسيت وحامض السلسليك و التسميد الازوتي والعضوي علي مكافحة الهالوك وانتاجية الفول البلدي

سعيد حراجي محمد عبدالحليم(1)، عادل احمد عمران فكار (2)، ياسر عبدالصبور محمد خليفه(1)، أحمد هاشم أحمد إبراهيم أنمران

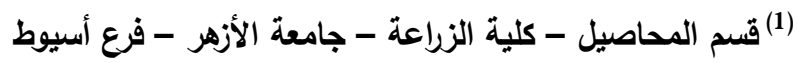

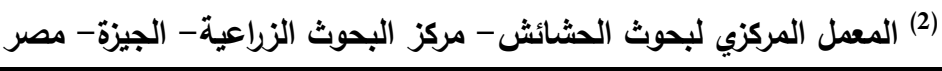

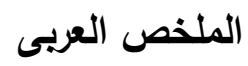

يصاب الفول البلاي بثدة بالهالوك بالوجه القبلى نظرا للارتفاع الثديد فى درجات الحرارة مما أدى إلى انذفاض المساحة المنزرعة بالفول البلاي. لذا تم إقامة تجريتين حقليتين في حقول مصابة بالهالوك بمحطة

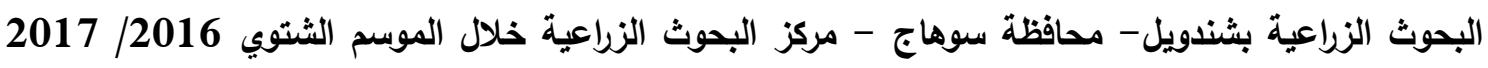

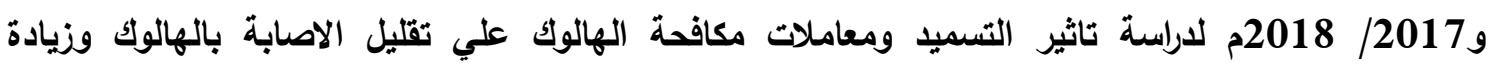

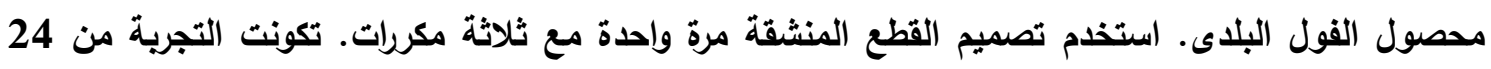

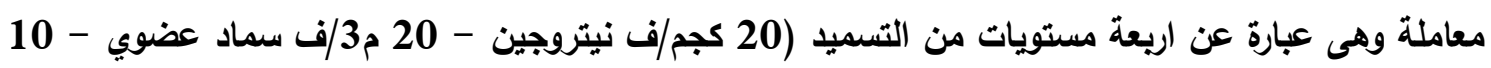

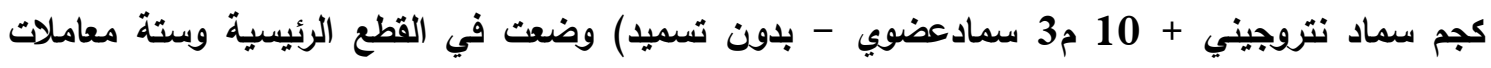

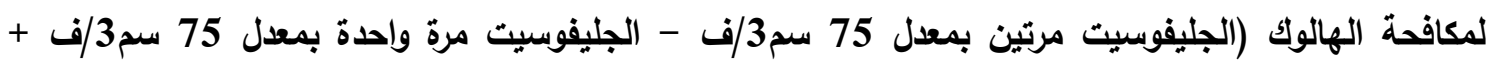

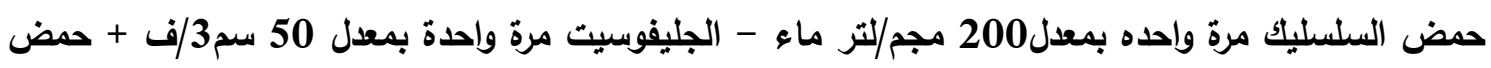

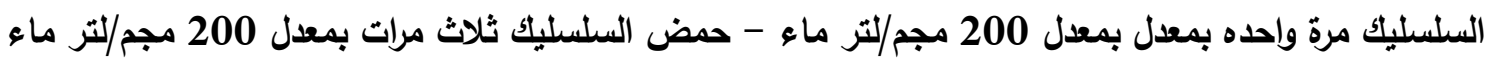

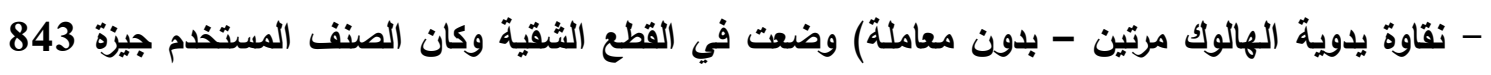

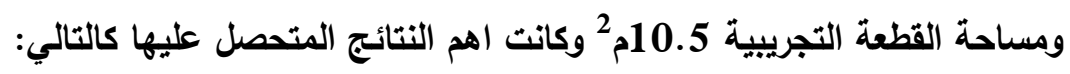
أدت اضافة السماد النتروحيني بمعل 20 كجم/ف وكنلك التسميد النتروجيني بمعل 10 كجم/ف+ تسميد

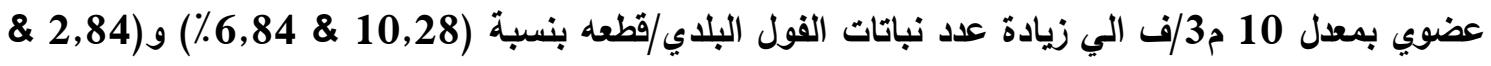

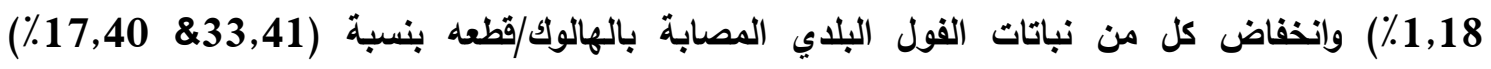

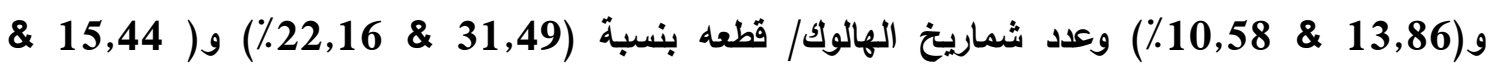

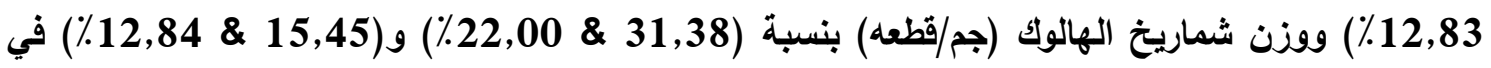

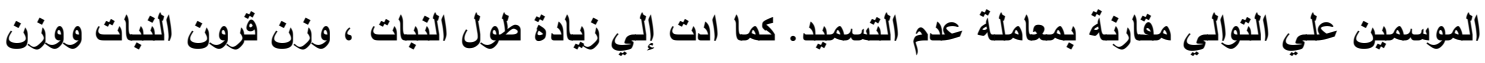
بذور النبات ووزن الـ100 بذرة ومحصول البذور/ف في الموسمين مقارنة بعدم إضافة السماد الأزوتى. 
ادي رش مبيد الجليفوسيت مرتين بمفردة او الجليفوسيت مرة واحدة + حمض السلسليك مرة واحده إلي

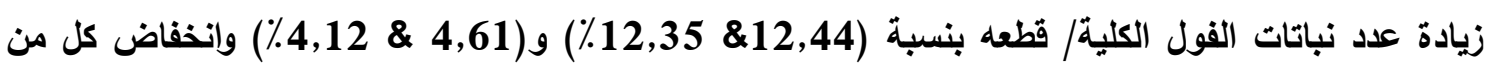
نباتات الفول البلاي المصابة بالهالوك/قطعه بنسبة (59,43 \& 46,69\%) و (52,52 \& 51,54\%) وعدد

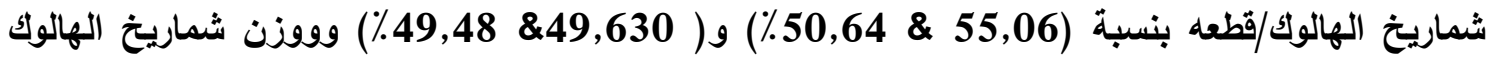
(جم/ قطعه) بنسبة (55,10 \& 50,69\%) و \& 49,62 \& 49,47) في الموسمين علي التوالي مقارنة بمعاملة عدم التسميد. كذلك ادت هذه المعاملة ايضا إلي زيادة فى زيادة طول النبات ، وزن قرون النبات ووزن بذور النبات ووزن الـ100 بذرة ومحصول البذور/ف في الموسمين مقارنة بدون معاملة. من خلال هذه الدراسة يمكن استخدام حض السلسليك كبديل امن علي النبات والبيئه كاتجاه جديد في مكافحة الهالوك وزيادة انتاجية القول البلاي 
S.H.M. Abd-El-Haleem, et al., 